\title{
Does the Use of Botulinum Toxin Reduce the Intensity of Myofascial Pain in Adult Patients?
}

\section{A Systematic Review and Meta-Analysis}

Letícia Maira Wambier ${ }^{1,3, *}$, Maria Fernanda Pivetta Petinati ${ }^{1}$, Paola Corso ${ }^{1}$, Carla Frehner Andrade ${ }^{1}$, Juliana Larocca de Geus $^{3,4}$, Rafaela Scariot ${ }^{2}$, Aline Monise Sebastiani ${ }^{1,2}$, Ana Claudia Rodrigues Chibinski ${ }^{3}$

${ }^{1}$ School of Health Science, Dentistry, Positivo University, Curitiba, Paraná, Brazil

${ }^{2}$ Department of Stomatology, Federal University of Parana, Curitiba, Paraná, Brazil

${ }^{3}$ Department of Dentistry, State University of Ponta Grossa, Ponta Grossa, Paraná, Brazil

${ }^{4}$ Department of Dentistry, Paulo Picanço School of Dentistry, Fortaleza, Ceará, Brazil

"Corresponding author: Letícia Maira Wambier, School of Health Science, Dentistry, Positivo University, Curitiba, Paraná, Brazil. Department of Dentistry, State University of Ponta Grossa, Ponta Grossa, Paraná, Brazil

Received date: 21 October, 2021 |

Accepted date: 8 November, $2021 \mid$

Published date: 11 November, 2021

Citation: Wambier LM, Petinati MFP, Corso P, Andrade CF, Larocca de Geus J, et al. (2021) Does the Use of Botulinum Toxin Reduce the Intensity of Myofascial Pain in Adult Patients? A Systematic Review and Meta-Analysis. J Dent Oral Epidemiol 1(1). doi https://doi.org/10.54289/JDOE2100107

Copyright: ( 2021 Wambier LM, et al. This is an open-access article distributed under the terms of the Creative Commons Attribution License, which permits unrestricted use, distribution, and reproduction in any medium, provided the original author and source are credited.

\section{Abstract}

Objective: A systematic review was performed to evaluate if the use of botulinum toxin was able to reduce the intensity of myofascial pain compared to other treatments in adult patients.

Material and Methods: A comprehensive search was carried out in the MEDLINE via Pub-Meb, Scopus, Web of Science, LILACS, BBO and Cochrane Library. In addition, the gray literature was also researched. The risk of bias tool from the Cochrane Collaboration was used by two independent reviewers for quality assessment of the studies.

Results: A total of 4372 studies were identified, 9 remained in qualitative study, 8 of these studies were considered at "unclear" risk of bias and just one study was "low" risk of bias in the key domains. Only two studies presented similar data to be included in the meta-analysis. Both studies evaluated the pain relief used the botulinum toxin (BTX-A) versus saline solution. The meta-analysis demonstrated that after 3 months follow-up the pain relief was 15.70 (95\% confidence interval $[\mathrm{CI}]=0.80$ to $30.61 ; \mathrm{p}=0.04)$.

Conclusion: The BTX-A reduced the intensity of myofascial pain compared to saline solution in adults after 3 months. However, further studies should be conducted to corroborate this finding.

Keywords: Meta-analysis; Myofascial Pain Syndromes; Botulinum Toxins.

Abbreviations: TMD: Temporomandibular disorders, TMJ: temporomandibular joint, MPS: myofascial pain syndrome, BTX-A: Botulinum Toxin Type A, CI: confidence interval, LI-LACS: Latin American and Caribbean Health Sciences Literature database, BBO: Brazilian Library in Dentistry, RCTs: randomized clinical trials, GRADE: Grading of Recommendations: Assessment, Development and Evaluation, MPQ: Mc GillPain Questionnaire. 


\section{Introduction}

Temporomandibular disorders (TMD) have been attributed a group of clinical conditions involving the temporomandibular joint (TMJ), masticatory muscles and associated structures [1]. In the adult non-patient population, TMD have been affected approximately $33 \%$ at least one symptom TMD sign in $40 \%-75 \%$ of the population [1]

TMD most common symptom is pain in the temporomandibular joint (TMJ), in the periauricular area or masticatory muscles, TMJ sounds, and by deviations or restricted jaw opening capacity [2]. TMD diagnosis on the determination of pathology using an anatomic and functional etiology, is divided into arthrogenic or myofascial TMD, respectively $[3,4]$. Generally, myofascial disorders are the most common TMD complaint of patients seeking treatment [5]. Myofascial pain is related with the pain from hyperfunctioning masticatory muscles leading to chronic myositis [3].

The myofascial pain syndrome (MPS) is increasingly present in the routine of people due to increased stress, environmental conditions and hormonal factors [6]. The individual may present chronic or acute pain in the region of the chewing muscles, usually with the formation of trigger points that may be active or inactive. The individual suffering from MPS can experience from functional difficulties such as chewing and talking to social restrictions due to the pain process, bringing psychosocial damage from depression [6].

The myofascial pain rate is $50 \%$ to $75 \%$ of the population at some point in their lives and another $20 \%$ to $25 \%$ of $\%$ population suffer symptoms but do not seek treatment [7]. This represents a major social and public health impact worldwide. According to the American Academy of Orofacial Pain and other worldwide consensus, treatment should always begin in the most conservative forms, such as the use of myorelaxant plaques and counseling, evolving step by step according to the individual responsiveness of the patient and intensity of the pain. The use of medications such as anti-inflammatory, muscle relaxants, antidepressants and anticonvulsants should also be considered [2, 8-11].

Botulinum toxins are produced by a gram-positive anaerobic bacterium called Clostridium botulinum. The Botulinum Toxin Type A (BTX-A) is a neurotoxin that blocks acetylcholine from the nerve endings producing dose-related weakness or paralysis of the skeletal muscles [12]. Regarding TMD, TBX-A is routinely used in recent years as primary or complementary treatment for MPS $[3, \mathbf{1 3}]$. In addition, it is also used for treating bruxism, disorders associated with TMJ disk displacement and habitual mandibular dislocation [12]. In special, on MPS treatment the BTX-A has been demonstrated advantages as pain relief [14]. TxB-A presents anti-inflammatory and analgesic action, because besides inhibiting the release of acetylcholine, TxB-A would have an inhibitory action on other neurotransmitters and neuropeptides, such as glutamate, CGRP and substance P responsible for the neurotransmission and/or peripheral and central sensitization of the pain pathway $[\mathbf{1 5}, \mathbf{1 6}]$.

Although the use of botulinum toxin has become popular, there is little evidence of its effectiveness in reducing myofascial pain and improving function over time. Thus, this systematic review compared the use of botulinum toxin to other treatments reduce the intensity of myofascial pain in adult patients.

\section{Material and Methods}

This study was registered on International Prospective Register of Systematic Reviews (PROSPERO) database under the number CRD42020141166 and follow the PRISMA recommendations $[\mathbf{1 7}, \mathbf{1 8}]$. It was performed from August 2019 to March 2020, at on University Positivo (UP), Curitiba, Paraná, Brazil.

The search strategy was developed the basis of the concepts of population, intervention, and comparison (PICOS) Within each concept, we combined the controlled (Medical Subject Headings terms) and free keywords with the Boolean operators OR and AND. The PICOS acronym was:

1. Population $(\mathrm{P})$ : adult patients with myofascial pain

2. Intervention (I): botulinum toxin

3. Comparison $(\mathrm{C})$ : other treatments (saline solution, laser therapy and occlusal splints).

4. Outcome $(\mathrm{O})$ : decreased the intensity of myofascial pain

5. Study type $(\mathrm{S})$ : randomized clinical trials

To identify trials to be included for this review, we searched on the electronic databases MEDLINE via PubMeb, Scopus, Web of Science, Latin American and Caribbean Health Sciences Literature database (LILACS), Brazilian Library in 
Dentistry (BBO) and Cochrane Library (Table 1). An expert library (D.M.) guided the whole search strategy. We handsearched the reference lists of all primary studies for additional relevant publications and the related articles link of each primary study in the PubMed database. No restrictions were placed on the publication date or languages.

Additionally, the gray literature was investigated how the: International Association for Dental Research and its regional divisions (2000 - 2019), the database System for Information on Grey Literature in Europe, and dissertations and theses using the ProQuest Dissertations and Theses full-text database as well as the Periodicals Capes Theses database. Records of clinical trials were also investigated: Current Controlled Trials, International Clinical Trials Registry Platform, ClinicalTrials.gov, Rebec and EU Clinical Trials Register.

For the eligibility criteria we included randomized clinical trials (RCTs) with parallel or cross-over designs in adults that compared the use of botulinum toxin versus active treatments for reduce the intensity of myofascial pain. Full-text versions of the papers that meet the eligibility criteria were retrieved for further assessment and data extraction. The RCT studies were excluded if: no treatment other than BTX-A was used; participants took analgesics or anti-inflammatory drugs during the treatment.

For the select the studies, the articles were selected by title and abstracts. Articles appearing in more than one database were considered only once. Full-text articles were also obtained when the title and abstract presented insufficient information to make a clear decision. Subsequently, two reviewers classified those that met the inclusion criteria (MFPP and PC). Each eligible article received a study ID, combining the first author and year of publication.

The most important information about the studies was extracted independently through customized forms. When there were multiple reports of the same study (i.e., reports with different follow-ups), data from all reports were extracted directly into a single data collection form to avoid over lapping data. The collection form was pilot tested using a sample of study reports to ensure that the criteria were consistent to the research question.

Two independent reviewers (MFPP and PC) performed quality assessment of the trials using the Cochrane Collaboration's tool for assessing risk of bias in RCTs [19]. The assessment criteria contained five items: sequence generation, allocation conceal-ment, the blinding of the outcome assessors, incomplete outcome data and selective out-come reporting. In case of disagreements between the reviewers were resolved through discussion, and if needed, by consulting a third reviewer (LMW).

The judgment for each entry involved recording 'yes' indicating low risk of bias, 'no' indicating high risk of bias, and 'unclear' indicating either lack of information or uncertainty over the potential for bias, as described in the Cochrane Handbook for Systematic reviews of Interventions 5.1.0. Two out of the six domains in the Cochrane risk of bias tool as key domains [20]. At the study level, studies were judged to be at "low" risk of bias if they were judged as low risk in the key domains sequence generation and allocation concealment. If one or more key domains were classified as at "unclear" risk of bias, the study was considered to be at "unclear" risk and if at least one domain was judged as "high" risk of bias, the study as a whole was judged as at "high" risk of bias.

Table 1 - Electronic databases and search strategy.

Pubmed $=685(02 / 03 / 2020)$

\#1

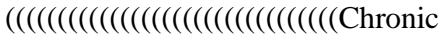

Pain [MeSH Terms]) OR

Myofascial Pain

Syndromes[MeSH Terms]) OR

"Chronic Pain"[Title/Abstract])

OR "Myofascial Pain

Syndromes"[Title/Abstract]) OR

"Temporomandibular

disorder"[Title/Abstract]) OR
\#2

Toxins[MeSH Terms]) OR Laser Therapy[MeSH Terms]) OR Placebos[MeSH Terms]) OR Occlusal Splints[MeSH Terms]) OR Botulinum Toxins, Type A[MeSH Terms]) OR "Botulinum Toxins"[Title/Abstract]) OR "Laser Therapy"[Title/Abstract]) OR

Placebos[Title/Abstract]) OR "Occlusal

Splints"[Title/Abstract]) OR "Botulinum Toxins Type A"[Title/Abstract]) OR
\#3 ((randomized controlled trial[pt] OR controlled clinical trial[pt] OR randomized controlled trials[mh] OR random allocation[mh] OR double-blind method[mh] OR singleblind method[mh] OR clinical trial[pt] OR clinical trials[mh] OR ("clinical trial"[tw]) OR ((singl*[tw] OR doubl*[tw] OR trebl*[tw] OR tripl*[tw]) AND (mask*[tw] OR blind*[tw])) OR (placebos[mh] OR placebo*[tw] OR random*[tw] OR research design[mh:noexp] OR comparative study[pt] OR evaluation studies as topic[mh] OR follow-up studies[mh] OR prospective studies[mh] OR 


\begin{tabular}{|l|l|l|}
\hline \hline $\begin{array}{l}\text { "Myofascial } \\
\text { Pain"[Title/Abstract]))) }\end{array}$ & $\begin{array}{l}\text { botox[Title/Abstract]) OR "muscle relaxant } \\
\text { plate"[Title/Abstract]))) }\end{array}$ & $\begin{array}{l}\text { control*[tw] OR prospective*[tw] OR voluneer*[tw]) NOT } \\
(\text { animals[mh] NOT humans[mh])))))))))) }\end{array}$ \\
\hline
\end{tabular}

\#1 AND \#2 AND \#3

Scopus $=349(02 / 03 / 2020)$

\#1( ( TITLE-ABS-KEY ( "ChronicPain" ) OR TITLE-ABS-KEY ( "Myofascial PainSyndromes" ) OR TITLE-ABS-KEY ( "Temporomandibulardisorder*" ) OR TITLE-ABS-KEY ( "MyofascialPain" ) ) )

\#2 ( ( TITLE-ABS-KEY ( "BotulinumToxin*") OR TITLE-ABS-KEY ( "LaserTherap*" ) OR TITLE-ABSKEY ( placebo* ) OR TITLE-ABS-KEY "OcclusalSplints" ) OR TITLE-ABS-KEY "BotulinumToxinsType A" ) OR TITLE-ABS-KEY ( botox ) OR TITLE-ABS-KEY ( "musclerelaxantplate" ) ) ) AND ( LIMIT-TO ( SUBJAREA, "DENT" )) AND ( LIMIT-TO ( DOCTYPE, "ar" ))

\section{\#1 AND \#2}

\section{Web of Science - $349(02 / 03 / 2020)$}

\#1 TS=("chronic Pain*") OR TS=("Temporal Muscle") OR TS=("Temporomandibular disorder") OR TS=("Temporomandibular Joint Disorder") OR TS=("Temporomandibular Joint Dysfunction Syndrome") OR TS=("Myofascial Pain") OR TS=("Myofascial Pain Syndrome") OR TS=("Myofascial Pain Dysfunction Syndrome") OR TS=("Temporomandibular Joing") OR TS=("Temporomandibular Disorder") OR TS=("Temporomandibular Joing Dysfunction Syndrome") OR $\mathrm{TS}=($ "Temporomandibular Joint Disorders") OR TS=("Myofascial Pain Syndromes") Índices $=S C I-E X P A N D E D, \quad S S C I, \quad A \& H C I, \quad C P C I-S$, CPCI-SSH, ESCI Tempo estipulado=Todos os anos
\#2 TS=(Lasers) OR TS=(botox) OR TS=("Alternative treatment") OR TS=("Anesthetic Local") OR $\mathrm{TS}=($ "Botulinum Toxin") OR TS=("Laser Therapy") OR $\mathrm{TS}=($ Methylprednisolone) OR TS=("Medication Therapy Management") OR TS=(Placebo) OR TS $=($ Injection\$) OR TS=("Botulinum Toxins Type A") OR TS=(physiotherapy) OR TS=("muscle relaxant plate") OR TS=("Occlusal Splints") OR TS=("Botulinum Toxins")

Índices $=S C I-E X P A N D E D, S S C I, A \& H C I, C P C I-S, C P C I-$ SSH, ESCI Tempo estipulado=Todos os anos

\section{\#1 AND \#2}

\section{Lilacs and $B B O=183(02 / 03 / 2020)$}

\#1 (mh:((MH: chronic pain OR MH: myofascial pain syndromes) )) OR (tw:(("dor crônica" OR "chronic pain" OR "dolor crónico" OR "dor miofascial" OR "myofascial pain syndromes" OR "dolor miofascial" OR "temporomandibular disorder" OR "desorden temporomandibular" OR "trastorno temporomandibular" OR "myofascial pain")))
\#2 (mh:((MH:botulinum toxins OR MH: laser therapy OR MH: placebos OR MH: oclusal splints OR MH: botulinum toxins,type A OR "botulinum toxins" OR "toxinas botulínicas" OR "toxinas botulínicas" OR "laser therapy" OR "terapia con láser" OR laserterapia OR placebos OR "oclusal splints" OR "férulas oclusales" OR "dispositivos interoclusais" OR "botulinum toxins type A" OR "toxinas botulínicas tipo A" OR botox OR "muscle relaxant plate" OR "placa relajante muscular" OR "placa relaxante muscular"))) OR (tw:(("botulinum toxins" OR "toxinas botulínicas" OR "toxinas botulínicas" OR "laser therapy" OR "terapia con láser" OR laserterapia OR placebos OR "oclusal splints" OR "férulas oclusales" OR "dispositivos interoclusais" OR "botulinum toxin stype A" OR "toxinas botulínicas tipo A" OR botox OR "muscle relaxant plate" OR "placa relajante muscular" OR "placa relaxante muscular")))

\section{\#1 AND \#2}

Cochrane Library $=2721(02 / 03 / 2020)$

\#1 MeSH descriptor: [Chronic Pain] explode all trees OR MeSH descriptor: [Myofascial Pain Syndromes] explode all trees OR ("Myofascial Pain Syndromes"):ti,ab,kw OR (Temporomandibular disorder*):ti,ab,kw OR ("Myofascial Pain"):ti,ab,kw OR ("Chronic Pain"):ti,ab,kw (Word variations have been searched)
\#2 MeSH descriptor: [Botulinum Toxins] explode all trees OR MeSH descriptor: [Laser Therapy] explode all trees OR MeSH descriptor: [Placebos] explode all trees OR MeSH descriptor: [Occlusal Splints] explode all trees MeSH descriptor: [Botulinum Toxins, Type A] explode all trees OR (Botulinum Toxin*):ti,ab,kw OR (Laser Therap*):ti,ab,kw OR (Placebo*):ti,ab,kw OR ("Occlusal Splints"):ti,ab,kw OR ("Botulinum Toxins Type A"):ti,ab,kw OR (botox):ti,ab,kw OR ("muscle relaxant plate"):ti,ab,kw 
were used in the meta-analysis of each outcome. We calculated the means difference and the $95 \%$ confidence interval (IC). Heterogeneity was assessed using the Cochran Q test and $\mathrm{I}^{2}$ statistics.

The quality of the evidence was graded for each outcome across studies (body of evidence) using the Grading of Recommendations: Assessment, Development and Evaluation (GRADE) to determine the overall strength of evidence for each meta-analysis. The GRADE approach is used to contextualize or justify intervention recommendations with four levels of evidence quality, ranging from high to very low.

The GRADE approach begins with the study design (RCTs or observational studies) and then addresses five reasons (risk of bias, imprecision, inconsistency, indirectness of evidence, and publication bias) to possibly rate down the quality of the evidence ( 1 or 2 levels) and three to possibly rate up the quality (large effect; management of confounding factors; dose-response gradient). Each one of these topics was assessed as "no limitation"; "serious limitations" and "very serious limitations" to allow categorization of the quality of the evidence for each outcome into high, moderate, low, and very low. The "high quality" suggests that we are very confident that the true effect lies close to the estimate of the effect. On the other extreme "very low quality" suggests that we have very little confidence in the effect estimate and the estimate reported can be substantially different from what it was measured.

\section{Results:}

After the database screening and removal of duplicates, 1741 studies were identified (Figure 1). After title screening, 62 studies remained. This number was reduced to 13 after examination of the abstracts and their full texts were assessed to check eligibility. Among them, 4 were excluded because: i) Botox was also used in the control group [21]; and ii) not checked the intensity of myofascial pain [22-24].

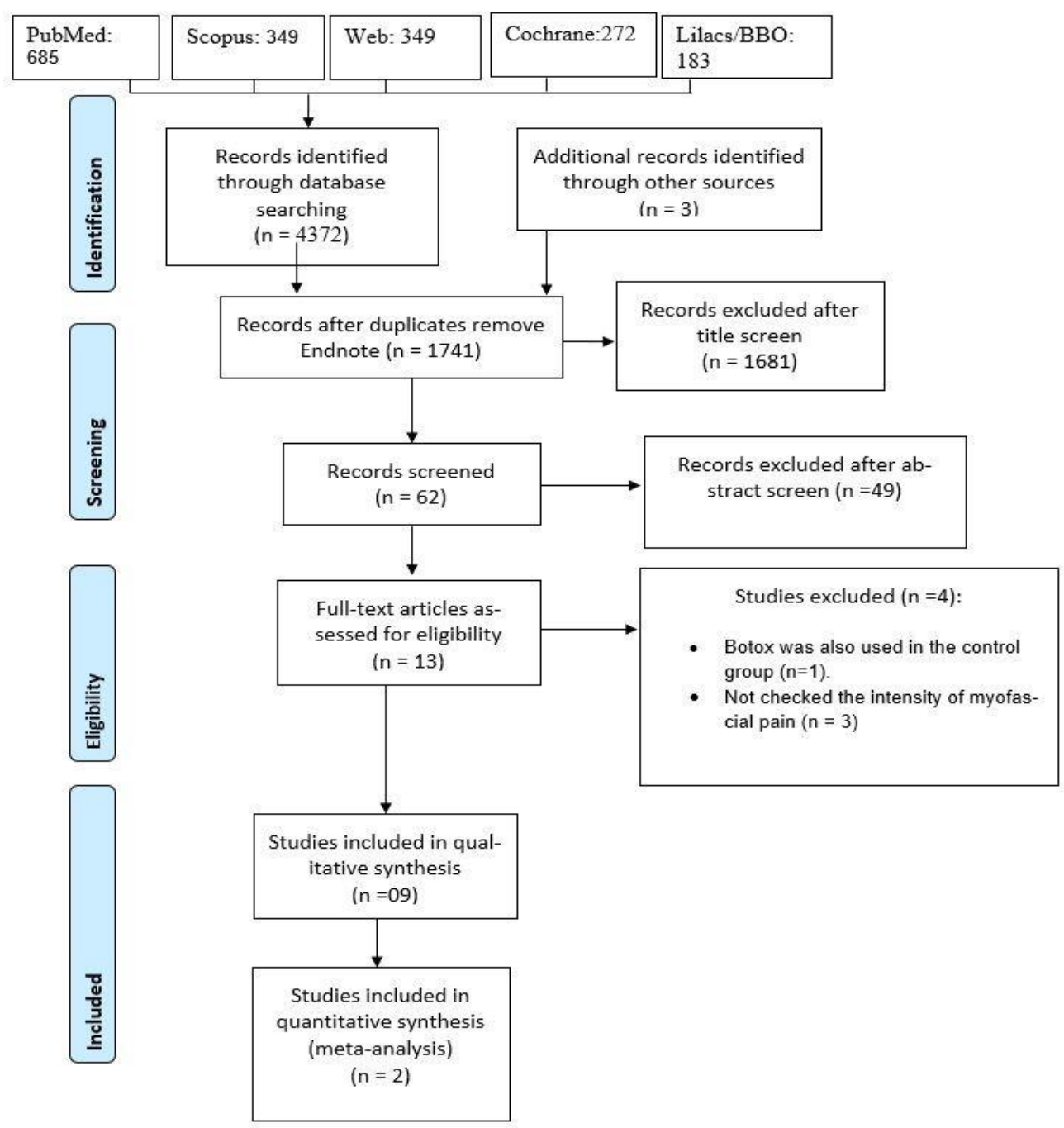

Figure 1 - Flow diagram of study. 


\section{Characteristics of included articles}

The characteristics of the 9 selected studies are listed in Table

2 and Table 3. Three studies used the cross-over [25-27]

design e 6 studies parallel design [28-33]. The studies were performed in different countries, 2 were performed in Canada

$[25,26]$, and one study in other countries: Saudi Arabia [28],
Brazil [29], Sweden [27], Italy [30], India [31], Germany [32] and US [33].

The mean age of the participants included in the clinical trials was approximately 44 years; however, this information was not reported in 4 studies [25, 30-32]. The percentage of males was $16 \%$ in 6 studies $[\mathbf{2 5 - 2 7}, \mathbf{2 9}, \mathbf{3 0}, \mathbf{3 3}]$, but this information was not reported in 3 studies $[\mathbf{2 8}, \mathbf{3 1}, \mathbf{3 2}]$.

Table 2- Summary of the studies selected for this systematic review.

\begin{tabular}{|c|c|c|c|c|c|c|c|c|c|c|}
\hline Study ID & $\begin{array}{l}\text { Study } \\
\text { design }\end{array}$ & $\begin{array}{l}\text { Cou } \\
\text { ntry }\end{array}$ & $\begin{array}{c}\text { Study } \\
\text { Outcome }\end{array}$ & $\begin{array}{l}\text { Subjects' } \\
\text { age mean } \\
\pm \text { SD } \\
\text { [range] } \\
\text { (years) }\end{array}$ & $\begin{array}{c}\text { No. } \\
\text { of } \\
\text { male } \\
\text { subj } \\
\text { ects } \\
{[\%]}\end{array}$ & $\begin{array}{l}\text { Total } \\
\text { No. } \\
\text { patient } \\
\text { s } \\
\text { [drop- } \\
\text { outs] }\end{array}$ & $\begin{array}{l}\text { Interven } \\
\text { tion } \\
\text { Group } \\
\text { [brand] }\end{array}$ & BTX-A units (U) & $\begin{array}{l}\text { Control } \\
\text { Group } \\
\text { [brand] }\end{array}$ & $\begin{array}{l}\text { Diagnostic } \\
\text { methods }\end{array}$ \\
\hline $\begin{array}{l}\text { Al-Wayli } \\
2017(28)\end{array}$ & Parallel & $\begin{array}{l}\text { Saud } \\
\text { i } \\
\text { Arab } \\
\text { ia }\end{array}$ & $\begin{array}{l}\text { Evaluate the role of } \\
\text { BTX-A in the } \\
\text { Treatment of pain } \\
\text { associated with } \\
\text { nocturnal bruxism }\end{array}$ & $\begin{array}{lr}45.5 & \pm \\
10.8 & (20- \\
60) & \end{array}$ & n.r. & $\begin{array}{l}\mathrm{T}=50 \\
\mathrm{I}=25 \\
\mathrm{C}=25 \\
\text { [n.r. }]\end{array}$ & $\begin{array}{l}\text { BTX-A } \\
\text { (Botox, } \\
\text { Allergan } \\
\text { Inc.) }\end{array}$ & $\begin{array}{l}20 \mathrm{U} \text { per side }(3 \\
\text { points } \\
\text { masseter) } \\
\mathrm{T}=40 \mathrm{U}\end{array}$ & $\begin{array}{l}\text { Tradicional } \\
\text { methods [resurance } \\
\text { and detailed } \\
\text { explanation of the } \\
\text { nature of } \\
\text { thedisease, } \\
\text { occlusal splints and } \\
\text { pharmacologic } \\
\text { measures] }\end{array}$ & $\begin{array}{l}\text { Bruxism } \\
\text { [questionnarie } \\
\text { (n.r.) clinical } \\
\text { examination } \\
\text { (n.r) signs and } \\
\text { symptoms] }\end{array}$ \\
\hline $\begin{array}{l}\text { De Carli et } \\
\text { al } \\
2016(29)\end{array}$ & Parallel & $\begin{array}{l}\text { Braz } \\
\text { il }\end{array}$ & $\begin{array}{l}\text { Compare the use of } \\
\text { low-level laser and } \\
\text { BTX-A in the } \\
\text { treatmentofmyofasci } \\
\text { alpainandwhetherthe } \\
\text { halterthemouthopeni } \\
\text { ngofpatientswithtem } \\
\text { poromandibulardiso } \\
\text { rder }\end{array}$ & $\begin{array}{l}38 \\
\text { n.r. }\end{array}$ & 13 & $\begin{array}{l}\mathrm{T}=18 \\
\mathrm{I}=7 \\
\mathrm{C}=8 \\
{[0]}\end{array}$ & $\begin{array}{l}\text { Botulim } \\
\text { toxin } \\
\text { n.r. }\end{array}$ & $\begin{array}{l}\text { First, } 30 \mathrm{U} \text { per } \\
\text { point ( } 2 \text { in the } \\
\text { masseter muscle } \\
\text { and } 1 \text { in the } \\
\text { temporal muscle). } \\
\text { Fifteen days later } \\
15 \mathrm{U} \text { per point } \\
\mathrm{T}=500 \mathrm{U}\end{array}$ & $\begin{array}{l}\text { Low-level laser } \\
\text { therapy with } \\
\text { GaAlAs, } 1=830 \\
\mathrm{~nm} \text {, dose = } 80 \\
\mathrm{~J} / \mathrm{cm}^{2} \text { per point ( } 2 \\
\text { points in the } \\
\text { masseter muscle } \\
\text { and } 1 \text { point in the } \\
\text { temporal } \\
\text { muscle).Seven } \\
\text { applications within } \\
\text { 48-h intervals }\end{array}$ & $\begin{array}{l}\text { Clinical } \\
\text { examination } \\
\text { (n.r.) signs } \\
\text { and symptoms }\end{array}$ \\
\hline $\begin{array}{l}\text { Ernberg et } \\
\text { al } 2011 \\
(27)\end{array}$ & $\begin{array}{l}\text { Cross- } \\
\text { over }\end{array}$ & $\begin{array}{l}\text { Swe } \\
\text { den }\end{array}$ & $\begin{array}{l}\text { Efficacy of BTX-A } \\
\text { was inpatients with } \\
\text { persistent } \\
\text { myofascial Temporo } \\
\text { mandibular } \\
\text { disorders (TMD) }\end{array}$ & $\begin{array}{l}38 \pm 12 \\
\text { (n.r.) }\end{array}$ & 9.5 & $\begin{array}{l}\mathrm{T}=21 \\
\mathrm{I}=12 \\
\mathrm{C}=9 \\
{[0]}\end{array}$ & $\begin{array}{l}\text { BTX-A } \\
\text { (Botox; } \\
\text { supplied } \\
\text { by } \\
\text { Allergan } \\
\text { Norden } \\
\text { AB, } \\
\text { Uppland } \\
\text { sVäsby, } \\
\text { Sweden) }\end{array}$ & $\begin{array}{l}10 \mathrm{U}(0.1 \mathrm{ml}) \text { per } \\
\text { point. There are } 3 \\
\text { points, in the deep } \\
\text { posterior portion, } \\
\text { in the origin and } \\
\text { attachment of } \\
\text { masseter muscle. } \\
\mathrm{T}=\mathrm{U} \\
\text { (unilateral) / } 100 \mathrm{U} \\
\text { (bilateral) }\end{array}$ & $\begin{array}{l}\text { Saline solution } 0.1 \\
\text { ml per point. There } \\
\text { are } 3 \text { points, in the } \\
\text { deep posterior } \\
\text { portion, in the } \\
\text { origin and } \\
\text { attachment of } \\
\text { masseter muscle. }\end{array}$ & RDC/TMD \\
\hline $\begin{array}{l}\text { Graboski } \\
\text { et al } 2005 \\
(26)\end{array}$ & $\begin{array}{l}\text { Cross- } \\
\text { over }\end{array}$ & $\begin{array}{l}\text { Can } \\
\text { ada }\end{array}$ & $\begin{array}{l}\text { Compare the } \\
\text { effectiveness of } \\
\text { trigger point } \\
\text { injections using } \\
\text { BTX A versus } \\
\text { bupivacaine, both in }\end{array}$ & $\begin{array}{l}5.1 \pm 13.4 \\
\text { (n.r.) }\end{array}$ & 47 & $\begin{array}{l}\mathrm{T}=18 \\
\mathrm{I}=9 \\
\mathrm{C}=9 \\
{[1]}\end{array}$ & $\begin{array}{l}\text { BTX-A } \\
\text { [n.r.] }\end{array}$ & $\begin{array}{l}25 \mathrm{U} \text { per trigger } \\
\text { point } \\
\mathrm{T}=\text { n.r. }\end{array}$ & $\begin{array}{l}\text { Bupvacaine } 0.5 \% \\
\text { [n.r.] ; 1/2 cc per } \\
\text { trigger point }\end{array}$ & $\begin{array}{l}\text { Clinical } \\
\text { examination } \\
\text { for pain by } \\
\text { physiatrist }\end{array}$ \\
\hline
\end{tabular}




\begin{tabular}{|c|c|c|c|c|c|c|c|c|c|c|}
\hline & & & $\begin{array}{l}\text { combination with a } \\
\text { home-based } \\
\text { habilitation program }\end{array}$ & & & & & & & \\
\hline $\begin{array}{l}\text { Guarda- } \\
\text { Nardini et } \\
\text { al } \\
2012(30)\end{array}$ & Parallel & Italy & $\begin{array}{l}\text { Effectiveness of } \\
\text { BTX-A Injections } \\
\text { And physiatric } \\
\text { treatment provided } \\
\text { by means of Fascial } \\
\text { Manipulation } \\
\text { techniques in the } \\
\text { management of my } \\
\text { fascial pain of jaw } \\
\text { muscles }\end{array}$ & $\begin{array}{l}\text { n.r. } \\
(23-69) \\
I=47.7 \pm \\
14.3 \\
C=43.2 \pm \\
13.9\end{array}$ & $\begin{array}{l}8 \\
{[26]}\end{array}$ & $\begin{array}{l}\mathrm{T}=30 \\
\mathrm{I}=15 \\
\mathrm{C}=15 \\
\text { [n.r.] }\end{array}$ & $\begin{array}{l}\text { BTX-A } \\
\text { (Dysport } \\
\text { Ipsen, } \\
\text { Ltd., } \\
\text { UK) }\end{array}$ & $\begin{array}{l}\text { Total of } 150 \mathrm{U} \text { per } \\
\text { side. Five- } \\
\text { injections } \\
\text { minimum with a } \\
\text { reverse pyramid } \\
\text { pattern was } \\
\text { performed in the } \\
\text { masseter muscles, } \\
\text { and a chess-board } \\
\text { pattern was used } \\
\text { for the temporal is } \\
\text { muscles }\end{array}$ & $\begin{array}{l}\text { Fascial } \\
\text { Manipulation by } \\
\text { therapists (deep } \\
\text { digital pressure). } \\
\text { Three }( \pm 1) 50 \text { min } \\
\text { sessions on a week. }\end{array}$ & RDC/TMD \\
\hline $\begin{array}{l}\text { Jadhao et } \\
\text { al } 2017 \\
(31)\end{array}$ & Parallel & $\begin{array}{l}\text { Indi } \\
\mathrm{a}\end{array}$ & $\begin{array}{l}\text { Evaluate the effect } \\
\text { of BTX-A in the } \\
\text { treatment of } \\
\text { myofascial pain and } \\
\text { the occlusal force } \\
\text { characteristics of } \\
\text { masticatory muscles }\end{array}$ & $\begin{array}{l}\text { n.r. } \\
35)\end{array}$ & n.r. & $\begin{array}{l}\mathrm{T}=24 \\
\mathrm{I}=8 \\
\mathrm{C}=8 \\
\mathrm{P}=8 \\
\text { [n.r.] }\end{array}$ & $\begin{array}{l}\text { BTX-A } \\
\text { (Botox, } \\
\text { Allergan } \\
\text {, Inc., } \\
\text { Irivine, } \\
\text { CA, } \\
\text { USA) }\end{array}$ & $\begin{array}{l}\text { Intramuscular } \\
\text { injections for each } \\
\text { side }(30 \mathrm{U}) \text { with in } \\
\text { the masseter } \\
\text { muscles and three } \\
\text { injections }(20 \mathrm{U}) \\
\text { with in the anterior } \\
\text { temporalis } \\
\text { muscles, for a } \\
\text { treatment total of } \\
100 \mathrm{U}\end{array}$ & $\begin{array}{l}\text { Saline solution } \\
\text { injections: the } \\
\text { same of I. } \\
\text { P: no injections } \\
\text { were given }\end{array}$ & $\begin{array}{l}\text { Clinical } \\
\text { examination } \\
\text { and bed } \\
\text { partner }\end{array}$ \\
\hline $\begin{array}{l}\text { Von } \\
\text { Lindern et } \\
\text { al } \\
2003(32)\end{array}$ & Parallel & $\begin{array}{l}\text { Ger } \\
\text { man } \\
\mathrm{y}\end{array}$ & $\begin{array}{l}\text { Assess whether the } \\
\text { targeted reduction of } \\
\text { masticatory } \\
\text { muscular } \\
\text { hyperactivity by } \\
\text { local injection } \\
\text { treatment with BTX- } \\
\text { A can improve facial } \\
\text { pain headache } \\
\text { symptoms }\end{array}$ & n.r. & n.r. & $\begin{array}{l}\mathrm{T}=90 \\
\mathrm{I}=60 \\
\mathrm{C}=30 \\
\text { [n.r. }]\end{array}$ & $\begin{array}{l}\text { BTX-A } \\
\text { (Botox; } \\
\text { Allergan } \\
\text { Ettlinge } \\
\text { n, } \\
\text { German } \\
\text { y) }\end{array}$ & $\begin{array}{l}35 \mathrm{U} \text { in } 0.7 \text { mLof } \\
\mathrm{NaCl} \text { saline } \\
\text { injected in The } \\
\text { corresponding } \\
\text { muscles } \\
\text { masseter, } \\
\text { temporalis, } \mathrm{M} \text {. } \\
\text { perygoideus } \\
\text { medialis) }\end{array}$ & $\begin{array}{l}0.7 \mathrm{~mL} \text { of saline } \\
\text { solution injections: } \\
\text { the same of } \mathrm{I} \text {. }\end{array}$ & $\begin{array}{l}\text { Clinical } \\
\text { examination } \\
\text { and } \\
\text { standardized } \\
\text { questionnaire }\end{array}$ \\
\hline $\begin{array}{l}\text { Nixdorf et } \\
\text { al } 2002 \\
(25)\end{array}$ & $\begin{array}{l}\text { Cross- } \\
\text { over }\end{array}$ & $\begin{array}{l}\text { Can } \\
\text { ada }\end{array}$ & $\begin{array}{l}\text { BTX-A was } \\
\text { efficacious for the } \\
\text { treatment of chronic } \\
\text { moderate to severe } \\
\text { jaw muscle pain in } \\
\text { females }\end{array}$ & $\begin{array}{l}\text { n.r. } \\
33 \quad(18 \quad- \\
45)\end{array}$ & 0 & $\begin{array}{l}\mathrm{T}=30 \\
\mathrm{I}=15 \\
\mathrm{C}=15 \\
{[17]}\end{array}$ & $\begin{array}{l}\text { BTX- } \\
\text { A(Botox } \\
; \\
\text { Allergan } \\
\text { Markha } \\
\text { m ON, } \\
\text { Canada) }\end{array}$ & $\begin{array}{l}25 \mathrm{U} \text { of } 0.6 \mathrm{~cm} 3 \mathrm{in} \\
\text { each temporalis } \\
\text { and } 50 \mathrm{U} \text { of } 0.6 \mathrm{~cm} \\
\text { in each masseter } \\
\text { divided in three } \\
\text { points }\end{array}$ & $\begin{array}{l}0.9 \% \text { normal saline } \\
\text { in the same points }\end{array}$ & RDC/TMD \\
\hline $\begin{array}{l}\text { Ondo et al } \\
2018 \\
(33)\end{array}$ & Parallel & $\begin{array}{l}\mathrm{EU} \\
\mathrm{A}\end{array}$ & $\begin{array}{l}\text { Safety and efficacy } \\
\text { of BoNT-A } \\
\text { injections into the } \\
\text { masseter and } \\
\text { temporalis muscles } \\
\text { in patients with } \\
\text { symptom mastic } \\
\text { sleep bruxism. }\end{array}$ & $\begin{array}{l}47.4 \quad \pm \\
16.9(18- \\
85)\end{array}$ & 17 & $\begin{array}{l}T=23 \\
\mathrm{I}=13 \\
\mathrm{C}=10 \\
{[1]}\end{array}$ & $\begin{array}{l}\text { BoNT- } \\
\text { A, } \\
\text { Botox, } \\
\text { Allergan } \\
\text {, Irvine, } \\
\text { CA) }\end{array}$ & $\begin{array}{l}100 \mathrm{U} / \mathrm{mL} \text {. Sixty } \\
\text { units were Injected } \\
\text { bilaterally into the } \\
\text { masseter muscles } \\
\text { ( } 2 \text { sites) and } 40 \\
\text { units into the } \\
\text { bilateral } \\
\text { temporalis ( } 3 \text { sites) } \\
\text { with } \\
\text { anatomic/palpatio } \\
\mathrm{n} \text { localization with }\end{array}$ & $\begin{array}{l}\text { n.r. } \\
\text { The same of I. }\end{array}$ & $\begin{array}{l}\text { Physical } \\
\text { examination } \\
\text { in } \\
\text { questionnaire } \\
\text { with } \\
\text { a modified } \\
\text { quantifiable } \\
\text { portion (G. } \\
\text { Lavigne) }\end{array}$ \\
\hline
\end{tabular}




\begin{tabular}{|l|l|l|l|l|l|l|l|l|l|l|}
\hline & & & & & & & & $\begin{array}{l}\text { a 28 gauge 1/2-in } \\
\text { needle. }\end{array}$ & & \\
\end{tabular}

$\mathrm{T}:$ Total

D :Dropout

lWave

I Intervention Group

C Control Group

$\mathrm{P}$ placebo

n.r.: not reported

n.a.: not applicable

*IQR - interquartile range;

SEM Standard error of mean;

Variations in Index of bite force distribution symmetry

BoNT-A - onabotulinum toxin-A

(BTX-A)- botulinum toxi

The total number of patients was on average 33 patients, 4 studies $[28,30-32]$ did not report this information.

All studies used BTX-A as treatment in the intervention group, only one study used BONT-A [33] and one study [29] did not report which botulin toxin was used. The BTX-A units changed between in the studies, one study used $20 \mathrm{U}$ per side [28], other used $30 \mathrm{U}$ per point and after 15 days used $15 \mathrm{U}$ per point [29], one study used $10 \mathrm{U}(0.1 \mathrm{ml})$ per point [27], other [26] used $25 \mathrm{U}$ per trigger point, one [30] used a total of $150 \mathrm{U}$ per side. One study [31] used intramuscular injections for each side (30 U) within the masseter muscles and three injections (20 $\mathrm{U})$ within the anterior temporalis muscles. One [32] used $35 \mathrm{U}$, other [25] used $25 \mathrm{U}$ of $0.6 \mathrm{~cm}^{3}$ in each temporalis and $50 \mathrm{U}$ of $0.6 \mathrm{~cm}$ in each masseter divided in three points. Another one [33] used a $100 \mathrm{U} / \mathrm{mL}$, sixty units were injected bilaterally into the masseter muscles (2 sites) and 40 units into the bilateral temporalis (3 sites) withanatomic/palpation localization with a 28 gauge 1/2inneedle.
The control treatment varied between studies but three studies [25, 27, 31] used saline solution. One study [28] used traditional methods (occlusal splints and pharmacologic measures), other [29] used a low-level laser therapy, one study [26] used Bupivacaine $0.5 \%$, other study [30] used the fascial manipulation by therapists and one [33] not report the control treatment.

For the method of diagnosing myofascial pain the most studies used the clinical examination method without specifying the criteria for diagnosis $[26,28,29,31,32]$, another studies $[\mathbf{2 5}, \mathbf{2 7}, \mathbf{3 0}]$ used the RDC / TMD (Research diagnostic criteria for temporomandibular disorders) and one study [33] used the physical examination.

In the table 3 shows the pain scale used between studies and all studies used de VAS scales. The follow-up period of the treatments for myofascial pain ranged from baseline to 12 months. Most of studies presented the values of the control group and the intervention group to assess VAS for pain relief just 3 studies [26, 29, 31] not reported this for the most of studies [25, 27, 28, 30, 32, 33]. 
Table 3- Summary of the results reported in the included studies in this systematic review.

\begin{tabular}{|c|c|c|c|c|c|}
\hline \multirow[t]{2}{*}{ Study ID } & \multirow[t]{2}{*}{ Pain Scale } & \multirow[t]{2}{*}{ Follow-up } & \multicolumn{2}{|c|}{ Mean \pm SD $($ median) of Pain } & \multirow[t]{2}{*}{ Function Evaluation } \\
\hline & & & $\begin{array}{c}\text { VAS } \\
\text { PAIN RELIEF }\end{array}$ & $\begin{array}{l}\text { VAS } \\
\text { PAIN }\end{array}$ & \\
\hline $\begin{array}{l}\text { Al-Wayli } \\
2017(28)\end{array}$ & $\operatorname{VAS}(0-10 \mathrm{~cm})$ & $\begin{array}{c}\text { Pre- } \\
\text { operatively } \\
3 \text { weeks } \\
2 \text { months } \\
6 \text { months } \\
12 \text { months }\end{array}$ & $\begin{array}{c}\text { Pre } \\
\text { I: } 7.1 \pm 0.72 \\
\text { C: } 7.5 \pm 0.66 \\
3 \mathrm{w} \\
\text { I : } 4.6 \pm 0.56 \\
\text { C: } 5.4 \pm 0.58 \\
2 \mathrm{~m} \\
\text { I: } 2.5 \pm 0.59 \\
\text { C: } 4.3 \pm 0.48 \\
6-12 \mathrm{~m} \\
\text { I: } 0.2 \pm 0.51 \\
\text { C: } 2.1 \pm 0.58\end{array}$ & n.r. & n.r. \\
\hline $\begin{array}{l}\text { De Carli et } \\
\text { al } \\
2016(29)\end{array}$ & $\operatorname{VAS}(0-10 \mathrm{~cm})$ & $\begin{array}{c}1,15 \text { and } 30 \\
\text { days }\end{array}$ & n.r. & $\begin{array}{l}1 \text { day } \\
\text { I: } 7 \\
\text { C: } 7 \\
15 \text { days } \\
\text { I: } 3 \\
\text { C: } 2 \\
30 \text { days } \\
\text { I: } 3 \\
\text { C: } 2.5\end{array}$ & $\begin{array}{l}\text { Inter incisal distance in millimeters } \\
1 \text { day } \\
\text { I: } 41 \mathrm{~mm} \\
\text { C: } 39 \mathrm{~mm} \\
15 \text { days } \\
\text { I: } 42 \mathrm{~mm} \\
\text { C: } 38 \mathrm{~mm} \\
30 \text { days } \\
\text { I: } 41 \mathrm{~mm} \\
\text { C: } 37 \mathrm{~mm}\end{array}$ \\
\hline $\begin{array}{l}\text { Ernberg et } \\
\text { al } \\
2011(27)\end{array}$ & $\begin{array}{c}\text { VAS }(0-100 \mathrm{~mm}) \\
\text { Mc Gil Pain } \\
\text { Questionnaire } \\
\text { (MPQ) } \\
\text { Graded Chronic } \\
\text { Pain Scale (DP) } \\
\text { Characteristic Pain } \\
\text { Intensity (CPI) }\end{array}$ & $\begin{array}{l}\text { Baseline, } 1 \\
\text { and } 3 \text { months }\end{array}$ & $\begin{array}{c}1 \text { month } \\
\text { I : } 35 \pm 35 \\
\text { C: } 27 \pm 29 \\
3 \text { month } \\
\text { I }: 34 \pm 36 \\
\text { C: } 24 \pm 29 \\
\text { Characteristic Pain Intensity } \\
\text { (CPI) } \\
\text { Baseline } \\
\text { I }: 69 \pm 11 \\
\text { C: } 67 \\
\text { I } 14 \\
1 \text { month } \\
\text { I: } 61 \pm 15 \\
\text { C: } 65 \pm 15 \\
3 \text { month } \\
\text { I: } 58 \pm 14 \\
\text { C: } 65 \pm 11 \\
\text { Graded Chronic Pain Scale } \\
\text { (DP }[\mathrm{IQR} *]) \\
\text { Baseline } \\
\text { I : } 1 \pm 3 \\
\text { C: } 1 \pm 3 \\
1 \text { month } \\
\text { I : } 1 \pm 3 \\
\text { C: } 0 \pm 3 \\
3 \text { month } \\
\text { I : } 0 \pm 2 \\
\text { C: } 1 \pm 3\end{array}$ & n.r. & $\begin{array}{l}\text { Mc Gill Pain Questionnaire (MPQ) } \\
\qquad \begin{array}{c}\text { Baseline } \\
\text { I }: 10.8 \pm 4.2 \\
\text { C: } 11.5 \pm 5.5 \\
1 \text { month } \\
\text { I }: 9.0 \pm 6.2 \\
\text { C: } 9.8 \pm 4.7 \\
3 \text { month } \\
\text { I }: 9.9 \pm 5.7 \\
\text { C: } 9.5 \pm 4.4\end{array}\end{array}$ \\
\hline
\end{tabular}




\begin{tabular}{|c|c|c|c|c|c|}
\hline $\begin{array}{l}\text { Graboski } \\
\text { et al } 2005 \\
(26)\end{array}$ & $\begin{array}{c}\text { VAS (75\% of pain } \\
\text { leve) } 1\end{array}$ & 7 days & n.r. & $\begin{array}{c}\text { Pre-injection: } 6.9 \pm \\
1.6 \\
\text { Trigger points: } 6.1 \pm \\
2.1 \\
\text { I: n.r. } \\
\text { C: } \text { n.r. }\end{array}$ & n.r \\
\hline $\begin{array}{l}\text { Guarda- } \\
\text { Nardini et } \\
\text { al., } \\
\text { 2012(30) }\end{array}$ & $\begin{array}{c}\text { VAS }(0-10- \\
\text { number })\end{array}$ & $\begin{array}{l}\text { Base line and } \\
3 \text { months }\end{array}$ & $\begin{array}{c}\text { Baseline-Immediate post- } \\
\text { injetcion } \\
\mathrm{I}=5.2 \pm 2.1 \\
\mathrm{C}=21 \pm 1.4 \\
\text { Baseline }-3 \text { months post- } \\
\text { injection } \\
\mathrm{I}=4.8 \pm 2.0 \\
\mathrm{C}=2.5 \pm 2.2\end{array}$ & n.r. & 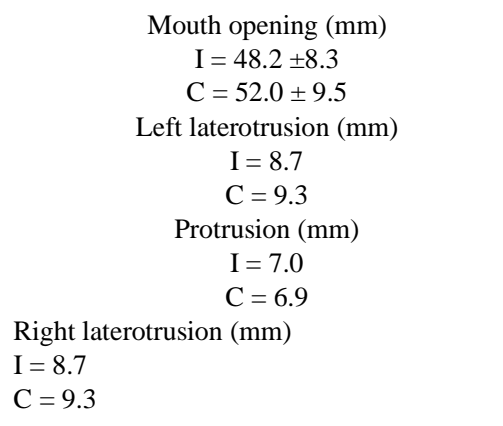 \\
\hline $\begin{array}{l}\text { Jadhao et } \\
\text { al } \\
2017(31)\end{array}$ & $\begin{array}{l}\text { VAS }(0-5 \mathrm{~cm}) \\
\text { Maximum bite } \\
\text { force }\end{array}$ & $\begin{array}{c}\text { Baseline, } 1 \\
\text { week, } 3 \\
\text { months and } 6 \\
\text { months }\end{array}$ & n.r. & $\begin{array}{c}\text { Pain at rest } \\
\text { Baseline } \\
\text { I : } 3.80 \pm 1.13 \\
\text { C: } 8 \pm 1.17 \\
1 \text { week } \\
\text { I : } 3.55 \pm 1.19 \\
\text { C: } 7.65 \pm 1.78 \\
3 \text { months } \\
\text { I : } 3.2 \pm 1.8 \\
\text { C: } 8.1 \pm 1.14 \\
6 \text { months } \\
\text { I : } 3 \pm 0.95 \\
\text { C: } 7.7 \pm 1.94 \\
\text { Pain at clenching } \\
\text { Baseline } \\
\text { I : } 3.10 \pm 1.3 \\
\text { C: } 8.14 \pm 2.82 \\
1 \text { week } \\
\text { I : } 3.55 \pm 1.19 \\
\text { C: } 7.65 \pm 2.07 \\
3 \text { months } \\
\text { I : } 3.2 \pm 1.8 \\
\text { C: } 8.1 \pm 1.4 \\
6 \text { months } \\
\text { I : } 3 \pm 0.95 \\
\text { C: } 7.7 \pm 1.94\end{array}$ & $\begin{array}{c}\text { Mean } \pm \text { SEM } \\
\text { Maximum Bite Force } \\
\text { Baseline } \\
\text { I : } 32.43 \pm 7.85 \\
\text { C: }-5.18 \pm 11.03 \\
1 \text { week } \\
\text { n.r. } \\
3 \text { months } \\
\text { I : - } 37.64 \pm 10.95 \\
\text { C: }-17.07 \pm 11.9 \\
6 \text { months } \\
\text { I : } 30.12 \pm 12.34 \\
\text { C: }-27.9 \pm 16.54 \\
\text { Variations in Index } \\
\text { Baseline } \\
\text { I : } 0.23 \pm 2.56 \\
\text { C: } 4.57 \pm 5.19 \\
1 \text { week } \\
\text { n.r. } \\
3 \text { months } \\
\text { I : - } 3.23 \pm 3.53 \\
\text { C: }-2.49 \pm 4.58 \\
6 \text { months } \\
\text { I : - } 5.23 \pm 3.21 \\
\text { C: }-3.57 \pm 5.88\end{array}$ \\
\hline $\begin{array}{l}\text { Von } \\
\text { Lindern et } \\
\text { al } \\
2003(32)\end{array}$ & VAS (0 - 10 points $)$ & $\begin{array}{l}\text { Observation } \\
\text { period } \\
\text { between } 1 \text { to } \\
3 \text { months }\end{array}$ & $\begin{array}{c}\text { Saline Solution: } \\
\text { Improvement Pain } 0.4 \\
\text { points } \\
\text { 1month } \\
\text { I: average improvement of } \\
3.2 \text { points } \\
\text { C: average improvement } \\
0.4 \text { points }\end{array}$ & n.r. & n.r. \\
\hline $\begin{array}{l}\text { Nixdorf et } \\
\text { al., } \\
2002(25)\end{array}$ & VAS $(0-100 \mathrm{~mm})$ & $\begin{array}{l}\text { Baseline and } \\
8 \text { weeks }\end{array}$ & $\begin{array}{c}2 \text { months } \\
\mathrm{I}=19 \pm 31 \\
\mathrm{C}=1 \pm 16\end{array}$ & n.r. & $\begin{array}{c}\text { Maximum opening without pain } \\
\text { improvement }(\mathrm{mm}) \\
\mathrm{I}=0 \pm 11 \\
\mathrm{C}=10 \pm 9 \\
\text { Maximum opening irrespective of pain } \\
(\mathrm{mm}) \\
\mathrm{I}=3 \pm 5\end{array}$ \\
\hline
\end{tabular}


Journal of Dentistry and Oral Epidemiology

\begin{tabular}{|l|l|l|l|l|l|}
\hline & & & & \\
\hline $\begin{array}{l}\text { Ondo et al } \\
2018(33)\end{array}$ & $\begin{array}{l}\text { VAS }(0-100 \mathrm{~mm}) \\
\text { EMG recordings of } \\
\text { the masseter and } \\
\text { temporalis muscle }\end{array}$ & $\begin{array}{l}\text { Base line and } \\
\text { 4 weeks }\end{array}$ & $\begin{array}{l}\text { Score of Pain VAS } \\
\text { Change posttreatment }\end{array}$ & n.r. & \\
& & $\begin{array}{l}\text { I: } 65 \pm 19.6 \\
\text { C: } 44.2 \pm 14.3\end{array}$ & & \\
\hline
\end{tabular}

The function evaluation changed between the studies, one study [29] evaluate the interincisal distance in millimeters, one used the Mc Gill Pain Questionnaire [27], other access the mouth opening [30], other study [31] evaluation the Maximum Bite Force, one study analyze the maximum opening without pain improvement [25] and for studies not reported this information $[\mathbf{2 6}, \mathbf{2 8}, \mathbf{3 2}, \mathbf{3 3}]$.

\section{Assessment of the risk of bias}

The assessment of the risk of bias of the included studies is presented in Figure 2

\begin{tabular}{|c|c|c|c|c|c|}
\hline & 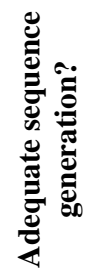 & 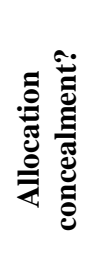 & 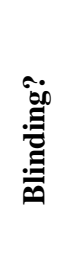 & 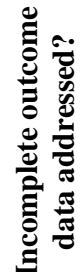 & 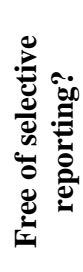 \\
\hline Al-Wayli, 2017 & & & ? & ? & \\
\hline De Carli et al., 2016 & & & & & \\
\hline Ernberg et al., 2011 & & & & & \\
\hline \multicolumn{6}{|l|}{ Graboski et al., 2005} \\
\hline \multicolumn{6}{|l|}{ Guarda-Nardini et al., 2012} \\
\hline \multicolumn{6}{|l|}{ Jadhao et al., 2017} \\
\hline \multicolumn{6}{|l|}{ Lindern et al., 2003} \\
\hline \multicolumn{6}{|l|}{ Nixdorf et al., 202} \\
\hline Ondo et al., 2018 & & & & & \\
\hline
\end{tabular}

Figure 2 - Summary of the risk of bias assessment according to the Cochrane Collaboration 
Some studies did not report the method of randomization and how the allocation concealment was performed. These 2 items were the key domains of the current systematic review. In the key domains of the Cochrane risk of bias tool, one of this study was judged as at "low" risk of bias [27]; and 8 studies were considered to be at "unclear" risk of bias [25, 26, 28-33].

\section{Assessment of the quality of evidence}

In the summary-of-findings table (Table 4), the meta-analysis was graded as moderate in the quality of evidence for pain relief. The reasons for downgrading the evidence were that the RCTs are at "unclear" risk of bias and presence imprecision with a high $95 \%$ confidence interval, which does not exclude important harm or benefit.

\section{Meta-analysis}

The meta-analyses were performed on studies classified as being at "unclear" or "low" risk of bias in the key domains and from the information could be extracted.

\section{Pain Relief}

The analysis was based on 2 studies [25, 27] that compared BTX-A versus saline solution. The means difference was 15.70 with a $95 \%$ confidence interval of 0.80 to 30.61 ( $\mathrm{p}=$ 0.04). The BTX-A showed superiority in the reducing the myofascial pain compared to saline solution. The data were not heterogeneous $\left(\mathrm{chi}^{2}\right.$ test $\mathrm{p}=0.63 ; \mathrm{I}^{2}=0 \%$; Figure 3$)$.

Figure 3- Forest plots of the pain relief at 3-month follow-up.

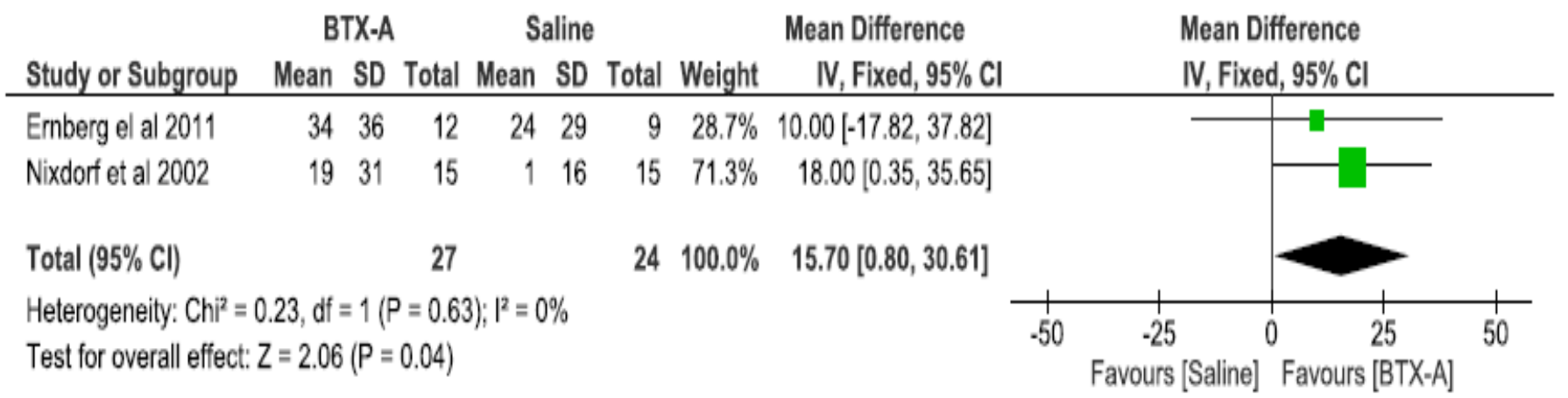

Table 4 - Summary of findings table.

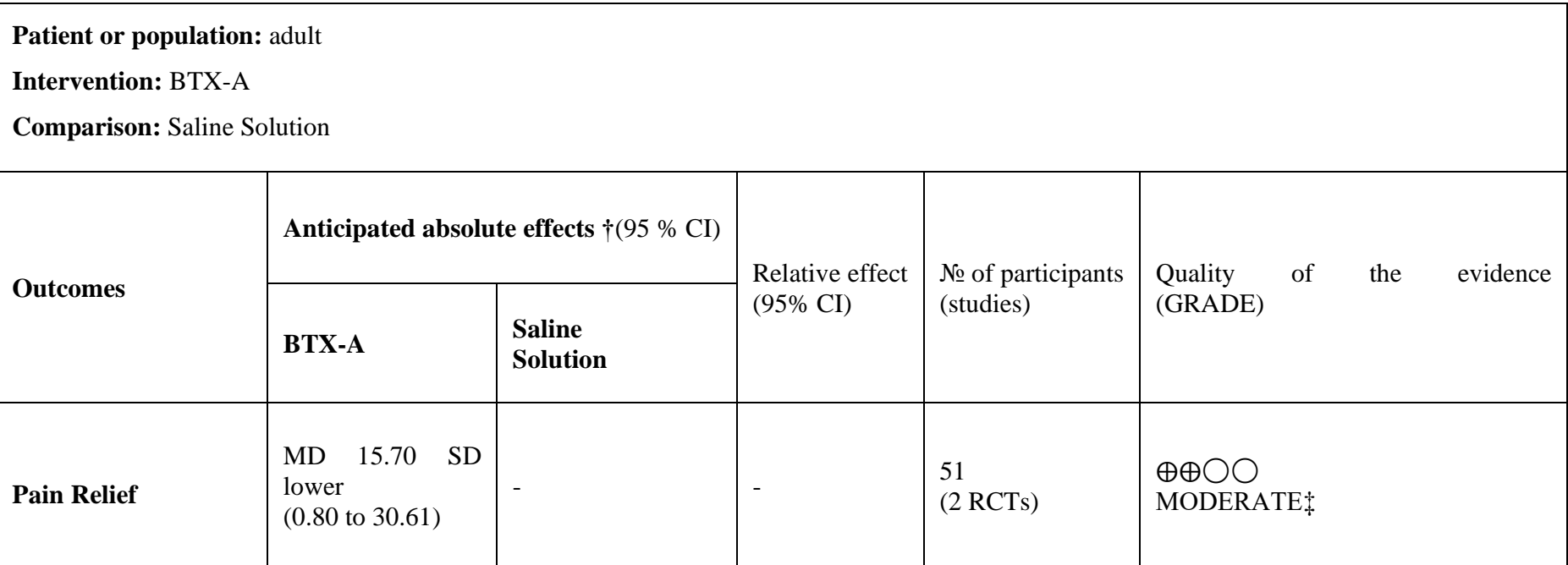

$\uparrow$ The risk in the intervention group (and its 95\% CI) is based on the assumed risk in the comparison group. $\$$ Imprecision and high risk of bias. CI, confidence interval; RCT, randomized clinical trials; MD, means difference. 


\section{Discussion}

When it comes to pain, due to being less tolerant, more sensitive and has lower thresholds, women frequently search for treatment for TMD symptoms in comparison to men. As such, a TMD is more prevalent in women, and it can be more frequent 3 to 6 times when compared to male gender $[\mathbf{3 4}, \mathbf{3 5}]$. Another possible hypothesis is the presence of estrogen receptors, absent in men, it may perform a predisposition in the development of joint disorders [36].

Conservative treatments, involving physical and relaxing therapy, which aim to restore a range of motion and release of muscle tension, such as: use of occlusal splints, physiotherapy and osteopathy are considered the first choice in the treatment of myofascial syndrome [2, 8-11]. Now the pharmacological interventions, such as the use of antiinflammatories, analgesics, muscle relaxants, as well as nonpharmacological methods such as dry needling, botulinum toxin injections, anesthetics injection, are considered adjunct treatment [37].

Four are the chewing muscles that can present some kind of dysfunction, which are temporal, masseter, lateral and medial pterygoid. However, most studies comprise only the application of botulinum toxin to the masseter and temporal muscles [33, 38-41], which can be justified by the fact that application to the medial pterygoid muscle leads to total paralysis of all the levator muscles of the mandible, and the lateral pterygoid muscle since they oppose the levator muscles and work to open the mandible

[41], besides the technical difficulty. Moreover, it is currently known that other muscles of the head and neck may also be involved in the pain process, which may generate a study bias. In any case, the application was mainly performed on the masseter muscle, not always occurring on the temporal muscle $[42,43]$. Some studies performed the injection of Botulinum toxin in the trigger points without specification of which muscle was addressed [44].

Some results are very difficult to compare because the pain is subjective. Thus, some works brought subjective results, such as the VAS scale, while others sought to find ways of objectifying some data such as the search for the evaluation of the function [38-41, 43]. Only a few studies have brought the newest "gold standard" as a way of quantifying the true state of pain, the Z-score, which has also limited the comparison with other data $[\mathbf{4 2}, \mathbf{4 4}]$.

Regarding the results of pain analysis, some authors evaluate the decrease of raw data $[\mathbf{3 8}, \mathbf{4 0}, \mathbf{4 4}]$, while others assess the pain relief $[33,39, \mathbf{4 1 - 4 3 , 4 5}$. The success of myofascial pain treatment can be considered when there is a $30 \%$ decrease in pain, and not necessarily its totality [46].

Important differences were not always observed when comparing the application of botulinum toxin and placebo by saline solution [41]. It is worth remembering that most of the time myofascial pains are due to the formation of trigger points, in which there is a decrease in oxygen flow and disorganization of muscle fibers. When a needle with or without saline solution is introduced, an inflammatory process may be initiated demanding oxygen and defense cells at the site, which refers to a very common treatment option in the treatment of this type of pain (dry needling), and it is possible to justify the improvement similar to the use of Botulinum toxin [47].

Due to the action of reducing the muscle strength of Botulinum toxin, the patient will experience a reduction in masticatory strength. However, it remains to be seen if the reduction of pain is really related to the suppression of masticatory function as well. For this reason, some authors include function tests in the studies. Nixdorf et al. (2002) [41] observed maximum opening decrease compared to patients who received placebo, which apparently does not offer damage in the quality of chewing. Another result evaluation criterion that varied widely was the measurement of the function's improvement, in which some authors evaluated a Mouth opening [38, 39], Mc GillPain Questionnaire (MPQ) [43] and Maximum Bite Force [40].

As for the diagnosis, the studies are poor in terms of the classification of chronic pain parameters or not. In general, when the process of chronic pain has already implied central sensitization, the botulinum toxin tends to have peripheral action on intra and extrafusal fibers, with no central modulation, which was also observed by [41] in a population of women with chronic and severe pain.

The correlation of other comorbidities (depression, headache and insomnia), as well as psychosocial aspects with the presence of myofascial pain and its prognosis, has also, 
been widely discussed in the literature. Especially in studies involving diagnosis through RDC/TMD, they did not bring the real importance of axis II aspects with the successful process of this type of treatment $[39,41,43]$.

The average duration of the drug's effect is 4 months [41]. Therefore, the patient and professional should be aware that the applications should be performed within this time, respecting the time intervals. However, some studies report that treatment with botulinum toxin presents a high cost in relation to other treatments $[\mathbf{4 1}, \mathbf{4 3}, \mathbf{4 4}]$, which makes it an enormous barrier for most people, being one of the factors for withdrawal of treatment [41]

The doses of applied botulinum toxin varied widely between studies. Some studies described the total dose applied, ranging from $40 \mathrm{U}[42]$ to $500 \mathrm{U}$ [38]. In addition, the way in which the doses were described makes comparison difficult, one of the studies reported only the dose per point but did not mention the number of points or the muscles that were applied to the drug [44].

The present systematic review showed, due to the little evidence available and most of the studies showing "unclear" risk of bias. There is a need for further investigations, especially randomized controlled clinical trials, testing alternatives to evaluate the application of botulinum toxin injection in decreasing pain intensity myofascial

Therefore, it is suggested that more randomized controlled clinical studies be carried out comparing the use of botulinum toxin to other MPS treatment techniques, since, even with good results obtained, few are found in the literature.

\section{Conclusion:}

The BTX-A reduce the intensity of myofascial pain compared to saline solution in adults after 3 months However, further studies should be conducted to investigate whether the use of BTX-A is able to reduce the intensity of myofascial pain in adults.

\section{References:}

1. De Leeuw R, Klasser G. (2008) American academy of orofacial pain. Orofacial pain: guidelines for assessment, diagnosis, and management Chicago: Quintessence. 316.
2. Leeuw R, Klasser G. (2018) Orofacial pain: guidelines for assessment, diagnosis, and management. 6th. Chicago: Quintessence.

3. Mor N, Tang C, Blitzer A. (2015) Temporomandibular myofacial pain treated with botulinum toxin injection. Toxins. 7(8): 2791-2800.

4. Schwartz M, Freund B. (2002) Treatment of temporomandibular disorders with botulinum toxin. Clin j pain. 18(6): S198-S203.

5. de Macedo Nery MB, de Gois Nery C, Leles CR. (2012) Profiling the clinical presentation of diagnostic characteristics of a sample of symptomatic TMD patients. BMC oral health. 12(1): 26.

6. Janal M, Raphael K, Nayak S, Klausner J. (2008) Prevalence of myofascial temporomandibular disorder in US community women. J oral rehab. 35(11): 801-809.

7. Smith P, Mosscrop D, Davies S, Sloan P, Al-Ani Z. (2007) The efficacy of acupuncture in the treatment of temporomandibular joint myofascial pain: a randomised controlled trial. J dent. 35(3): 259-267.

8. Truelove E, Huggins KH, Mancl L, Dworkin SF. (2006) The efficacy of traditional, low-cost and nonsplint therapies for temporomandibular disorder: a randomized controlled trial. J Am Dent Assoc. 137(8): 1099-1107.

9. Dworkin SF, Turner JA, Mancl L, Wilson L, Massoth D, et al. (2002) A randomized clinical trial of a tailored comprehensive care treatment program for temporomandibular disorders. J Orofac Pain. 16(4): 259276.

10. Vallon D, Akerman S, Nilner M, Petersson A. (2002) Long-term follow-up of intra-articular injections into the temporomandibular joint in patients with rheumatoid arthritis. Swed Dent J. 26(4): 149-158.

11. Conti PCR, De Alencar E, da Mota Correa A, Lauris JRP, Porporatti AL, et al. (2012) Behavioural changes and occlusal splints are effective in the management of masticatory Rehabil. 39(10): 754-760.

12. Bogucki ZA, Kownacka M. (2016) Clinical aspects of the use of botulinum toxin type a in the treatment of dysfunction of the masticatory system. Adv Clin Exp Med. 25(3): 569-573 
13. Kütük SG, Özkan Y, Kütük M, Özdas T. (2019) Comparison of the Efficacies of Dry Needling and Botox Methods in the Treatment of Myofascial Pain Syndrome Affecting the Temporomandibular Joint. J Craniofac Surg. 30(5): 1556-1559.

14. Dall'Antonia M, Netto RMdO, Sanches ML, Guimarães AS. (2013) Jaw muscles myofascial pain and botulinum toxin. Revista Dor. 14(1): 52-57.

15. Aoki K. (2005) Review of a proposed mechanism for the antinociceptive action of botulinum toxin type A. Neurotoxicology. 26(5): 785-793.

16. Sycha T, Samal D, Chizh B, Lehr S, Gustorff B, et al (2006) A lack of antinociceptive or antiinflammatory effect of botulinum toxin $\mathrm{A}$ in an inflammatory human pain model. Anesthesia \& Analgesia. 102(2): 509-516.

17. Moher D, Liberati A, Tetzlaff J, Altman DG. (2009) Preferred reporting items for systematic reviews and meta-analyses: the PRISMA statement. BMJ (Clinical research ed). 339: b2535.

18. Zorzela L, Loke Y, Loannidis JP, Golder S, Santaguida P, et al. (2016) PRISMA harms checklist: improving harms reporting in systematic reviews. BMJ. 353: i2229.

19. Higgins JP, Altman DG, Gotzsche PC, Juni P, Moher D, et al. (2011) The Cochrane Collaboration's tool for assessing risk of bias in randomised trials. BMJ (Clinical research ed). 343: d5928.

20. Higgins JP, Altman DG, Gotzsche PC, Juni P, Moher D, et al. (2011) The Cochrane Collaboration's tool for assessing risk of bias in randomised trials. Bmj. 343: d5928.

21. Park HU, Kim BI, Kang SM, Kim ST, Choi JH, et al. (2013) Changes in masticatory function after injection of botulinum toxin type A to masticatory muscles. J Oral Rehabil. 40(12): 916-922.

22. Kurtoglu C, Gur OH, Kurkcu M, Sertdemir Y, GulerUysal F, et al. (2008) Effect of botulinum toxin-A inmyofascial pain patients with or without functional disc displacement. J Oral Maxillofac Surg 66(8): 16441651.

23. Kutuk SG, Ozkan Y, Kutuk M, Ozdas T. (2019) Comparison of the Efficacies of Dry Needling and Botox Methods in the Treatment of Myofascial Pain Syndrome
Affecting the Temporomandibular Joint. The J Craniofac Surgery. 30(5): 1556-1559.

24. Zhang LD, Liu Q, Zou DR, Yu LF. (2016) Occlusal force characteristics of masseteric muscles after intramuscular injection of botulinum toxin A (BTX - A) for treatment of temporomandibular disorder. Br J Oral Maxillofac Surg. 54(7): 736-740.

25. Nixdorf DR, Heo G, Major PW. (2002) Randomized controlled trial of botulinum toxin $\mathrm{A}$ for chronic myogenous orofacial pain. Pain. 99(3): 465-473.

26. Graboski CL, Gray DS, Burnham RS. (2005) Botulinum toxin A versus bupivacaine trigger point injections for the treatment of myofascial pain syndrome: a randomised double blind crossover study. Pain. 118(1-2): 170-175.

27. Ernberg M, Hedenberg-Magnusson B, List T, Svensson P. (2011)Efficacy of botulinum toxin type A for treatment of persistent myofascial TMD pain: a randomized, controlled, double-blind multicenter study. Pain.152(9): 1988-1996.

28. Al-Wayli H. (2017) Treatment of chronic pain associated with nocturnal bruxism with botulinum toxin. A prospective and randomized clinical study. J Clin Exp Dent. 9(1): e112-e117.

29. De Carli BM, Magro AK, Souza-Silva BN, Matos Fde S, De Carli JP, et al. (2016) The effect of laser and botulinum toxin in the treatment of myofascial pain and mouth opening: A randomized clinical trial. J Photochem Photobiol B. 159: 120-123.

30. Guarda-Nardini L, Stecco A, Stecco C, Masiero S, Manfredini D. (2012) Myofascial pain of the jaw muscles: comparison of short-term effectiveness of botulinum toxin injections and fascial manipulation technique. Cranio. 30(2): 95-102.

31. Jadhao VA, Lokhande N, Habbu SG, Sewane S, Dongare S,et al. (2017) Efficacy of botulinum toxin in treating myofascial pain and occlusal force characteristics of masticatory muscles in bruxism. Indian J Dent Res. 28(5): 493-497.5

32. von Lindern JJ, Niederhagen B, Berge S, Appel T. (2003) Type A botulinum toxin in the treatment of chronic facial pain associated with masticatory hyperactivity. J Oral Maxillofac Surg. 61(7): 774-778. 
33. Ondo WG, Simmons JH, Shahid MH, Hashem V, Hunter C, et al. (2018) Onabotulinum toxin-A injections for sleep bruxism: A double-blind, placebo-controlled study. Neurology. 90(7): e559-e564.

34. Bush FM, Harkins SW, Harrington WG, Price DD. (1993) Analysis of gender effects on pain perception and symptom presentation in temporomandibular pain. Pain. 53(1): 73-80

35. Rieder CE, Martinoff JT, Wilcox SA. (1983) The prevalence of mandibular dysfunction. Part I: Sex and age distribution of related signs and symptoms. J Prosthet 50(1): 81-88.

36. Abubaker AO, Raslan WF, Sotereanos GC. (1993) Estrogen and progesterone receptors in temporomandibular joint discs of symptomatic and asymptomatic persons: a preliminary study. J Oral Maxillofac Surg. 51(10): 1096-1100.

37. Weller JL, Comeau D, Otis JAD. (2018) Myofascial Pain. Semin Neurol. 38(6): 640-643.

38. De Carli BMG, Magro AKD, Souza-Silva BN, de Souza Matos F, De Carli JP, et al. (2016) The effect of laser andbotulinum toxin in the treatment of myofascial pain and mouth opening: A randomized clinical trial. $\mathbf{J}$ Photochem Photobiol B. 159: 120-123.

39. Guarda-Nardini L, Stecco A, Stecco C, Masiero S, Manfredini D. (2012) Myofascial pain of the jaw muscles: comparison of short-term effectiveness ofbotulinum toxin injections and fascial manipulatio technique. CRANIO®. 30(2): 95-102.
40. Jadhao VA, Lokhande N, Habbu SG, Sewane S, Dongare S, et al. (2017) Efficacy of botulinum toxin in treating myofascial pain and occlusal force characteristics of masticatory muscles in bruxism. Indian J Dent Res. 28(5):493.

41. Nixdorf DR, Heo G, Major PW. (2002) Randomized controlled trial of botulinum toxin A for chronic myogenous orofacial pain. Pain. 99(3): 465-473.

42. Al-Wayli H. (2017) Treatment of chronic pain associated with nocturnal bruxism with botulinum toxin. A prospective and randomized clinical study. J Clin Exp Dent. 9(1): e112.

43. Ernberg M, Hedenberg-Magnusson B, List T, Svensson P. (2011) Efficacy of botulinum toxin type A for treatment of persistent myofascial TMD pain: a randomized, controlled, double-blind multicenter study. Pain. 152(9): 1988-1996.

44. Graboski CL, Gray DS, Burnham RS. (2005) Botulinum toxin A versus bupivacaine trigger point injections for the treatment of myofascial pain syndrome: a randomised double blind crossover study. Pain. 118(1-2): 170-175.

45. von Lindern JJ, Niederhagen B, Bergé S, Appel T. (2003) Type A botulinum toxin in the treatment of chronic facial pain associated with masticatory hyperactivity. Journal of oral and maxillofacial surgery. 61(7): 774-778.

46. Farrar JT, Portenoy RK, Berlin JA, Kinman JL, Strom BL. (2000) Defining the clinically important difference in pain outcome measures. Pain. 88(3): 287-294.

47. Kalichman L, Vulfsons S. (2010) Dry needling in the management of musculoskeletal pain. J Am Board Fam Med. 23(5): 640-64 